\section{Alma Vančura}

Josip Juraj Strossmayer University of Osijek

Croatia
2015, Vol. 12 (2), 113-124(244)

revije.ff.uni-lj.si/elope

doi: 10.4312/elope.12.2.113-124

UDC: 784.71 : [316.77:008] $=111=163.42$

\title{
Nonverbal Elements in War Poems across Cultures: A Case Study of English and Croatian
}

\author{
ABSTRACT
}

Building on extensive study on nonverbal communication, this paper focuses on the presence of culturally referenced representations of nonverbal behaviour in poetry, specifically looking at the presence of culturally referenced nonverbal elements in war poems written during and after World War I. Written representations of such nonverbal elements are seen either as vocalnonverbal (paralanguage) or as nonvocal-nonverbal (kinesics). As a poem's theme derives from the actual event(s), it can be expected to contain culturally bound nonverbal elements. Analysis shows that nonverbal elements are mostly represented via descriptions of spatial signs, body adaptors and bodily characteristics, and that the presence of culturally referenced nonverbal elements is almost non-existent.

Keywords: nonverbal communication; paralanguage; kinesics; culture; war poems; poetry

\section{Neverbalne prvine v vojnih pesmih z medkulturnega vidika: Študija primerov $v$ angleščini in hrvaščini}

\author{
POVZETEK
}

Članek izhaja iz številnih študij o neverbalni komunikaciji in obravnava prisotnost kulturno pogojenih reprezentacij neverbalnega vedenja $\mathrm{v}$ poeziji, predvsem prisotnost kulturno vezanih neverbalnih prvin v vojnih pesmih, napisanih med prvo svetovno vojno in po njej. Neverbalne prvine, izražene prek pisnega jezika, delimo na vokalno-neverbalne (parajezik) in nevokalnoneverbalne (kinezika). Ker tematika obravnavanih pesmi temelji na konkretnih dogodkih, je pričakovati, da bo vsebovala tudi kulturno pogojene neverbalne prvine. Analiza razkrije, da so neverbalne prvine prisotne predvsem $\mathrm{v}$ opisih prostorskih znakov, telesnih adaptorjev in telesnih značilnosti ter da kulturno pogojenih neverbalnih prvin skoraj ni zaznati.

Ključne besede: neverbalna komunikacija; parajezik; kinezika; kultura; vojne pesmi; poezija 


\section{Nonverbal Elements in War Poems across Cultures: A Case Study of English and Croatian}

"War and culture, those are the two poles of Europe, her heaven and hell, her glory and shame, and they cannot be separated from one another." Milan Kundera, Immortality

\section{Introduction}

\subsection{Nonverbal Communication and Nonverbal Elements}

Initially, nonverbal communication was viewed as "the exchange of information through nonlinguistic signs" (Harrison 1974, 25) covering the spectrum of stimuli not belonging to spoken or written words and mostly focusing on purposeful use of gestures, eye and body movements, and material things (Reusch and Kees 1971; Friesen et al. 1979); today this is mainly known under the term kinesics. The following example illustrates kinesics represented in written language - in a poem: "He sinks on one knee ${ }^{1}$ and now on the other, his upper body tilts in rigid inclination this way and back"2 (Jones 1991, 75).

However, very early on scientists understood that nonverbal communication cannot be exclusively tied to nonvocal features (Poyatos 1975) and that nonverbal cues should include not only the dichotomous distinction between verbal (lexical) and nonverbal (kinesic) features but also between vocal and nonvocal features.

Therefore, Laver and Hutcheson (1972) proposed four distinguishable categories that can serve as means of communication: (1) vocal-verbal (words), (2) vocal-nonverbal (intonation and paralanguage), (3) nonvocal-verbal (written or printed language), and (4) nonvocal-nonverbal (kinesics). The last category has been expanded to include "Total Body Communication [...], which includes acoustic, visual, olfactory, and tactile means of conveying cognitive (language replaceable) and indexical (speaker-identifying) information [...]” (Poyatos 1975, 286-87).

Most authors (for instance, Brooks 1978; McKerrow et al. 1999; Guerrero and Floyd 2006; Lucas 2009) now agree that nonverbal communication can be seen as "the emission of signs by all the nonlexical, artifactual and environmental sensible sign systems contained in the realm of culture, whether individually or in mutual co-structuration, and whether or not those emissions constitute behavior or generate interaction" (Poyatos 2002a, xvii). This rather exhaustive definition is used as a reference point in this paper as to what constitutes nonverbal communication and nonverbal behaviour.

Nonverbal behaviour is therefore represented by a wide spectrum of possible sign systems, that is, via various nonverbal elements. This paper focuses on written representations of such nonverbal elements, specifically culturally referenced nonverbal elements, as building blocks of a poem, working together with traditional literary devices to create vivid imagery in the poem and to stir emotions in the reader.

As in all subsequent quotes, underlining by the author.

In order to place the nonverbal element in the forefront, the examples do not follow the original structure of the poem (in terms of lines and capitalizations of letters). 


\subsection{Culture and Cultural Words}

Culture is an all-pervasive concept that can be understood and observed from many different standpoints. It is necessary to acknowledge that many definitions of culture (Argyle 1967; Lyons 1981) include language as an integral and essential part of culture. Sapir believes that language does not exist "apart from culture, that is, from the socially inherited assemblage of practices and beliefs that determines the texture of our lives" $(1970,207)$. Above all language serves for communication and therefore we could conclude that culture, language and communication are inseparable, or that culture is communication.

Each language contains words which are culturally referenced, that is, cultural words (Newmark $1988,94)$, which can be quite easily detected as they are associated with particular practices and customs. Sometimes even universal words, such as breakfast, can carry different cultural connotations depending on the referent and their cultural background. Newmark (1988) categorizes cultural words into several cultural categories: ecology (flora, fauna, plains, hills), material culture (food, clothes, houses and towns, transport), social culture (work and leisure), organizations, customs, activities, procedures, concepts (political and administrative, religious, artistic terms), history, gestures and habits. Pavlović and Poslek (1998) further subdivide history into historical events, functions, personalities, tradition, and add economy (concepts), education, and forms of address to the list. In this paper, we focus on nonverbal elements when they function as cultural words or, in this specific context, cultural elements.

\subsection{Literature and Poetry}

Ever since the beginning of time, man has yearned to express himself. "Literature is as old as human language $[\ldots]$ and the first literature in any culture was oral" (Carter and McRae 2001, 2). There are no brief and simple definitions of literature, as it encompasses various types of expressions, approaches, and techniques. Still, for the purpose of this paper, some definition is needed, and we will use Meyer's $(1987,3)$, which states that literature is "a fiction consisting of carefully arranged words designed to stir the imagination." We can say that stories, poems, and plays are fictional and fall under the category of being "imagined - even when based upon actual historic events" (Meyer 1987, 3).

Imagination is the key element of writers and poets who, by using facts or fiction, transform whatever is present in the material or immaterial world (people, places, objects, feelings, beliefs, values...) into experiences that the readers interpret as meaningful units. This transformation involves "channel reduction from multisensory perception to a visual text" (Poyatos 2008, 136), which reduces all the acoustic, tactile, kinesthetic, olfactory, visual bodily, environmental and gustatory signs to a visually written language or to what Laver and Hutcheson (1972) (see 1.1) call nonvocal-verbal category. Nonverbal elements that represent an inseparable part of communication now have to be described and evoked purely by verbal elements. Fortunately, the endless possibilities of words successfully function as transmitting devices of nonverbal elements that affect each individual's sensibility.

Traditionally, the analysis of poetry was done through critical theory or practical criticism, mostly by naming and defining the elements of poetic craft: meter, form, lineation, rhyme, syntax, diction, tone, voice, gender, and punctuation (see Meyer 1987; Oliver 1994; Lennard 2005). However, this paper tries a different approach to poetry. It explores how representations of nonverbal elements 
contribute to the overall imagery of poems, ${ }^{3}$ specifically war poems, and how many of these elements are culturally bound.

This paper analyses poetry that falls back on actual historic events, that is, poetry written during or after a period of the World War I. By using a cross-cultural approach, we aim at sensitizing the reader toward other people and cultures, in our case, Croatian and English. The reason for this is that "the writers' incisive observations and identification of their reality-based characters constitute an invaluable and reliable document on both people's behaviours and their interrelated environmental elements" (Poyatos 2002, xxvii).

\section{Rationale and Purpose}

As previously mentioned (1.3), poetry has been extensively explicated by painstakingly analysing verse, word choice, metaphors, similes, rhetorical figures, all in view of better understanding and appreciation of the genre. Although there has been elaborate work done on the subject of nonverbal elements in literature (Holoka 1992; Poyatos 2002b; Poyatos 2008), the focus has primarily been on prose rather than on verse genres (Lateiner 1996). This paper falls back on Holoka's $(1992,244)$ idea that by gathering "verbal descriptions of nonverbal communication, we may then assess it both on its merits and as it coordinates with spoken communications in the given work." By observing how poets transform into words what is considered a nonverbal behaviour we can gain insights into cultural and subcultural information, while possibly discovering the reasons why each culture conveys the unspeakable by portraying paralinguistic and kinesic behaviour. This paper attempts to evaluate the representation of culturally referenced nonverbal elements in poems, specifically war poems that address the topic of World War I. As poets in war poems draw on an actual historic event or events, and are "especially sensitive to the adequacy of language to register honest experience" (Fussell 1991, 34), we wanted to check how many culturally referenced nonverbal elements would appear in such poems. The purpose of this paper is to depict nonverbal elements as intrinsic elements of poetry, establish the occurrence of nonverbal elements in war poems and compare them crossculturally. The focus is on selecting the lines of poetry in which nonverbal elements are culturally referenced and in which they play an integral part in the artistic design of the poem.

\section{Corpus and Methodology}

Unlike the English speaking countries that have many anthologies dedicated to war poetry, particularly works covering the period of the two World Wars, the situation with war poems in Croatia is very different. Not because there are no poems written during or about those periods, but simply because at the time Croatia did not exist as an independent country. It was part of the Kingdom of Serbs, Croats and Slovenes, which was proclaimed in 1918 after World War I and which was known as the Kingdom of Yugoslavia from 1929 (Benson 2001). Since no such systematic anthology exists, ${ }^{4}$ a new corpus was created by combining different available anthologies and books of poetry, and choosing the most representative Croatian poets of the time. Fifty-four

\footnotetext{
The term imagery is taken in its broader sense; according to Abrams (1997, 121), it is "used to signify all the objects and qualities of sense perception referred to in a poem [...], whether by literal description, by allusion, or in the vehicles [...] of its similes and metaphors. [...] Also, imagery [...] includes not only visual sense qualities, but also qualities that are auditory, tactile (touch), thermal (heat and cold), olfactory (smell), gustatory (taste), or kinesthetic (sensations of movement)."

There is an anthology of war poems called U ovom strašnom času, antologija hrvatske ratne lirike (In this terrible moment, an anthology of modern Croatian war poems, translated by A.V.), but it contains poems written during and after the Croatian War of Independence (1991-1995). These poems belong to a different period than the one this paper is investigating, so the book was omitted from the corpus.
} 
war poems (10164 words) were analysed from The Norton Book of Modern War, and twenty-seven (9068 words) were analysed from the following books on poetry: Svitse konča, Antologija hrvatskoga pjesništva od početaka do danas; Izmedu dva rata, Novija Hrvatska lirika; Jedna antologija hrvatske poratne poezije; Medaši, Hrvatsko pjesništvo dvadesetoga stoljeća; Miroslav Krleža, Izabrane pjesme; Miroslav Krleža Poezija; Izbor za srednje škole; Tin Ujević, Izbor pjesama I; Antologija hrvatske poezije, od XIV stoljeća do naših dana. Two poets (Ivan Goran Kovačić and Jure Kaštelan) wrote about World War II, and not World War I, but were still included in the corpus. The reason for this is twofold: first, they are Croatian poets whose poems are quintessential war poems found in all poetry anthologies, and second, to balance the word count between English and Croatian corpora.

The first step in our analysis included identifying and recording the representations of nonverbal elements contained in war poems. In the second phase we checked whether such elements were culturally bound. The third step included analysis of the gathered data, and the final step was drawing conclusions from the obtained results.

\section{Results and Discussion}

\subsection{Overall Results}

We have previously established that nonverbal communication (see 1.1) encompasses a vast array of nonverbal behaviour, ${ }^{6}$ including not only kinesic (gestures, manners, posture, and body movements, object-adaptors) behaviours, which have been traditionally associated with nonverbal communication, but also paralinguistic (voice features, voice types, differentiators, alternants), sounds and silences, facial expression (gaze and eye behaviour), and proxemic (spatial) behaviour. Furthermore, nonverbal behaviour includes chemical reactions (visually, olfactorily or gustatorily perceived), thermal, dermal characteristics, body shape and size, colour of skin, hair, eyes and teeth, and clothing (Poyatos 2008). Simply put, everything can have a specific communicative value and be perceived as a nonverbal element, especially if the behaviour behind it is intentional and generates some kind of interaction. Such an exhaustive framework can pose a problem when it comes to systematic labelling and classification of nonverbal categories.

In this study, the written representations of nonverbal elements were divided into several categories: kinesic elements (generally covering everything connected with movement), paralinguistic elements (vocal category), spatial signs / proxemics, body adaptors, bodily characteristics and a miscellaneous category (chemical reactions, gustatory signs, thermal, dermal characteristics, etc.). In the total analysed corpora (20,232 words) only $5 \%$ or 1036 words ( 86 instances of nonverbal elements) were categorized as belonging to culturally referenced nonverbal elements. These 5\% are divided into categories as follows: body adaptors were represented with $29 \%$ of the total instances of nonverbal occurrences (English corpus 15\%, Croatian corpus 51\%). Next in terms

\footnotetext{
The World is Ending, an Anthology of Croatian poetry from the beginnings to the present day; Between the two Wars, New Croatian Poetry; An Anthology of Croatian post-war poetry; Milestones, Croatian poetry of the 20th century; Miroslav Krleža, Selected Poems;Miroslav Krleža Poetry, Selected poems for High School; Tin Ujević, Selected Poems I; An Anthology of Croatian Poetry, from the 14th century to the present (translated by A.V.).

6 Nonverbal behaviour can be observed from two standpoints: (1) that it serves to express a particular biological function and is mostly done involuntarily, or (2) that it reflects formerly functional behaviour that derives from our evolutionary history where it had a specific and direct function (biting, baring the teeth, wrinkling of the nose, etc.), eventually evolving and acquiring communicative value (Krauss et al. 1996, 389). Nonverbal elements in this paper are analysed from the latter standpoint, as each poem is observed as a written representation of culture which, as we have previously established (see 1.2), can be viewed as communication, consequently serving to render a particular message to the reader.
} 
of frequency were spatial signs / proxemics, with 27\% of occurrences (English 44\%, Croatian $13 \%)$, respectively. The miscellaneous category and bodily characteristics followed, with $14 \%$ each. Kinesic and paralinguistic categories had the least number of occurrences (both 9\%) (see Figure 1).

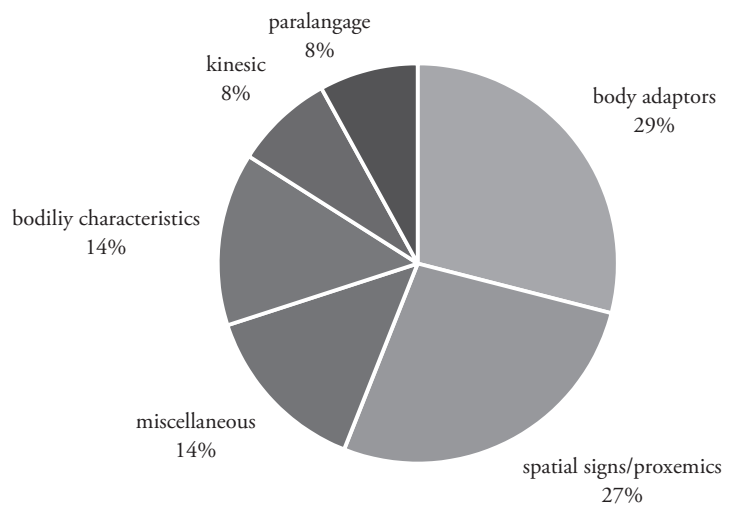

FIGURE 1. Categorization of culturally referenced nonverbal elements.

The results show differences in distribution within categories among the English and Croatian poets. We can divide the results into two major groupings. One, containing spatial signs / proxemics and body adaptors, which showed the highest difference in the number of occurrences between English and Croatian corpora (spatial signs / proxemics: English corpus 44\%, Croatian 13\% and body adaptors category: English corpus 15\%, Croatian corpus 51\%). The other grouping encompasses all other categories, namely bodily characteristics (8\% English, 3\% Croatian), miscellaneous (10\% English, 20\% Croatian), kinesic (10\% English, 8\% Croatian) and paralinguistic (13\% English, $5 \%$ Croatian), which were more evenly distributed (see Figure 2).

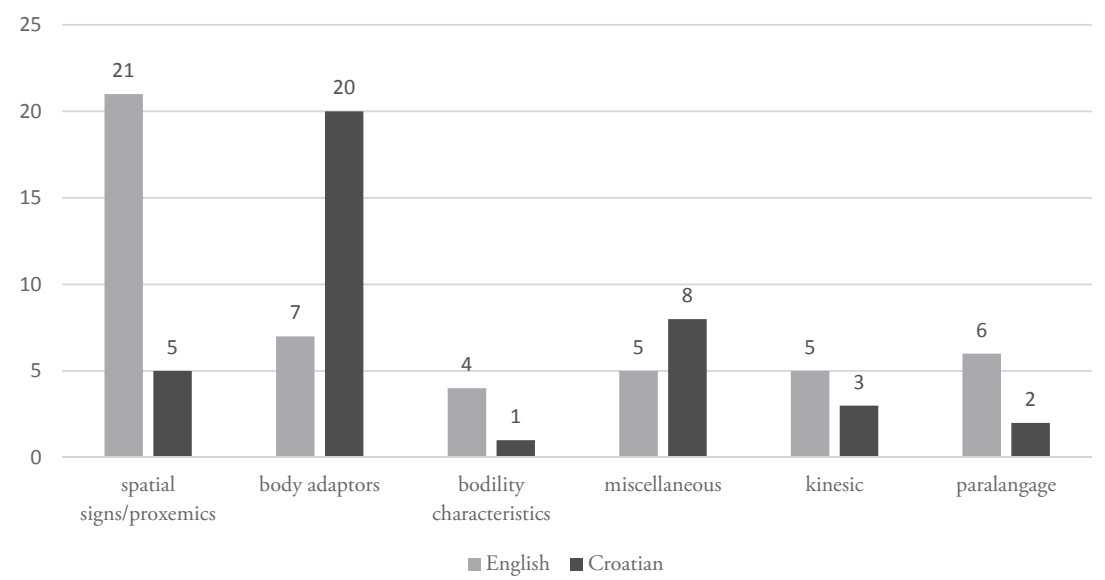

Figure 2. Occurrences of nonverbal elements - English and Croatian war poems.

\subsection{Spatial Signs / Proxemics}

The majority of the culturally referenced nonverbal elements for English poets refer to geographical names (21 occurrences). On the one hand, they mostly refer to the battlefields of France giving the poem its authenticity: "grunted Harry to Jack / as they slogged up to Arras" (Sassoon 1991b, 69). 
Another example which illustrates knowledge about a geographical place of historic and cultural significance is described in Johnstone's $(1991,198)$ "High Wood": "this is High Wood, / called by the French, Bois des Fourneaux, / the famous spot which in nineteen-sixteen, / July, August and September was the scene / of long and bitterly contested strife, / by reason of its high commanding site." Mentioning of nonverbal elements describing spatial signs often shows the poet's first-hand experience of being in a war zone, thus contributing to idea of registering "honest experience" (Fussell 1991, 34) like in the example: "Do you remember the dark months you held the sector at Mametz" (Sassoon 1991a, 199). In the analysed Croatian war poems, only five instances of spatial signs were found, out of which three refer to battlefields: Galicia (Krleža 1976a, 184), Sommacampagna and Solferino (Krleža 1976b, 190).

Culturally referenced spatial signs in English war poems, meanwhile, refer to various geographic names in Britain. These words often cover a universal function, but not the cultural description of a referent that the English reader can grasp and the Croatian cannot: "but we are rash levied from Islington and Hackney / and the purlieus of Walworth / flashers from Surbiton / men of the stock from Abraham / from Bromley-by Bow / Anglo-Welsh from Queens Ferry / rosary-wallahs from Pembrey Dock" (Jones 1991, 70-71). The poet is depicting enlisted soldiers coming from all walks of life and from different places in Britain. All these places have various cultural connotations for the British reader and almost none for the Croatian reader.

Croatian poets rarely use spatial signs and only two instances were found referring to actual places in Zagreb: Ban Jelačić Square (Ujević 2004, 151) and St. Mark's Square (Krleža, 1976c, 77) which are both places of important historic significance for Croatian people.

\subsection{Body Adaptors}

As war poems draw on actual historic events, it was expected that descriptions of external adaptors (Lateiner 1996) or body adaptors (Poyatos 2002a) would appear. These cover a wide spectrum of elements, such as food, clothes, perfume and cosmetics, eating utensils that have various meanings and social functions. Poyatos $(2002 \mathrm{~b}, 333)$ here places "objects most intimately related to the body which, consciously or unconsciously, can influence our co-interactants negatively or positively". Seven elements were found in the English corpus and twenty in the Croatian. The elements are predominantly connected with clothes, specifically uniforms, or flag colours. These clothes and colours can strongly influence the reactions of a character/reader, depending on whether the description is of an ally or of the enemy: "The grey militia marches over land" (Scannell 1991, 204), grey being the official uniform colour of the Austro-Hungarian Army. If the reader is unfamiliar with the colours of external adaptors in "In the afternoon the bells rang for the burial, [...] and all day one could hear the thunder of coffins / covered with black and yellow fabrics" (Krleža 1976d, 182), they will miss the cultural reference to the official flag of the former Austrian Empire. Croatia was under its military and civilian rule until the empire collapsed after World War I.

\subsection{Miscellaneous}

The miscellaneous category was represented by $14 \%$ of cases. It encompasses various subcategories into which nonverbal elements were classified. We believe that these subcategories are necessary in order to fully understand the totality of interactive processes that function in cooperation with language (perceptual mechanisms; see Poyatos 2002a) like olfactory, tactile, kinesthetic,

Originally in Croatian, translated by the author. 
and gustatory signs. The example: "I heard one murderer urinate loudly" (Kovačić 2005, 117) illustrates olfactory and kinaesthetic (auditory) experience that the reader can have while imagining the horrors of prisoners described in the poem. It also signifies the lack of manners one can witness in times of war - behaviour that would otherwise be completely socially unacceptable.

\subsection{Bodily Characteristics}

"The shape, size, consistency, weight and strength, color of skin, hair and eyes, and specifically facial features, can play extremely relevant roles in an encounter," claims Poyatos (2002b, 332). In poetry, the virtual encounter between the reader and the character(s) in the poem happens via written nonverbal descriptions, so poets pay special attention to the careful design of these elements.

It is interesting to see how hair and eye colour can be culturally bound, like in the E. E. Cummings (1991a) poem "i sing of Olaf glad and big," where Olaf is probably a second generation Swedish American from the Mid-West (Docherty 1995) and physically represents the Germanic warrior: "a yearning nation's blueeyed pride / [...] our president [...] / threw the yellowsonofabitch / into a dungeon $[\ldots]$ he was / more brave than me: more blond than you" (E. E. Cummings 1991a, 202).

\subsection{Kinesic Behaviour}

When we started doing research on the topic of written representations of culturally referenced nonverbal elements, we believed that the majority of elements would be represented via kinesic behaviour. The initial idea behind it was that since war poems draw on soldiers' experience and lives, military kinesic repertoire, which is attributed to cultural words, would be present in many poems. The results do not confirm this. Kinesic elements are represented with $9 \%$ in the total corpus.

In his seminal poem In Parenthesis, Jones provides the following description of kinesic behaviour: "Mr. Jenkins half inclined his head to them - he walked just / barely in advance of his platoon and immediately to the left of / Private Ball. / He makes the conventional sign / and there is the deeply inward effort of spent men who would / make response for him" (Jones 1991, 74). This is a depiction of a gesture which is used to display the army salute as a form of greeting and which Ekman and Friesen (1969) categorize as emblems.

Emblems are "nonverbal acts which have a direct verbal translation [...] usually consisting of a word or a phrase [...] well known by all members of a group, class or culture" (Ekman and Friesen $1969,63)$. In the example above, the group in the poem is represented by soldiers who all share the knowledge of what the emblem means as it has a quite specific, agreed-upon meaning. This nonverbal stimulus also functions as a regulator (Ekman and Friesen 1969, 82) that regulates interaction in a communication system, which is seen in the next line, as the soldiers accurately decode the signal and try to salute back. This culturally referenced element is shared by both Croatian and English readers, since the army salutes are, in this case, identical in both countries. In the Croatian corpus no such instances were found. There are, however, some examples of culturally referenced kinesic behaviour connected to religious customs: "did we not, the little ones, attend Midnight mass / where old funny ladies counted the rosary beads"- (Ujević 2005, 99); and to 
traditional customs: "and he is hanging black flags on the houses" ${ }^{10}$ (Krleža 1976e, 180), the black flag signifying death.

\subsection{Paralinguistic Elements}

Few culturally referenced nonverbal elements (9\% total; 13\% in the English and 5\% in the Croatian corpus) were found in the analysed corpora. Poyatos $(1993,6)$ defines paralanguage as "the nonverbal voice qualities, voice modifiers and independent utterances." How is paralanguage connected with culture? First, the human voice can produce numerous sounds and can reveal information about the speaker. ${ }^{11}$ Many vocal features (pronunciation of words, vowel position, phonetic markers, etc.) are culturally influenced and learned. Furthermore, we have previously established that language is culture (see 1.2) and one's culture is best reflected in one's personal language, one's idiolect (Newmark 1988).

Voice quality is an abstract notion that is difficult to label and categorize and we usually use impressionistic labels to talk about someone's voice. When it comes to audible and visual signs, describing paralinguistic behaviour is more difficult than describing other types of nonverbal repertoire. Nonetheless, poets often accompany written verbal exchanges with paralinguistic cues: "Jest chirped at gayest pitch" (Blunden 1991, 138). Latenier (1996, 246) claims that paralinguistic cues are inserted in poems "to color a moment." By using alternants, tone, laryngeal, respiratory control, different types of voice and pitch poets can indicate the emotional states of their characters, reveal the focus of their attention and provide invaluable cultural background.

Crystal $(1975,62)$ explains that each person while speaking produces "vocal effects which identify him as a member of a number of specific communities." These community qualities can cover race, class, occupational group, nation and culture. The following example shows how the use of paralinguistic behaviour can describe a type of speech and identify its speaker and its cultural heritage: "thy sons acclaim your glorious name by gorry by jingo by gee by gosh by gum" (E. E. Cummings 1991b, 203). The poet uses alliteration, the repetition of the initial sound $g$ to make an allusion to the speech of the American man of the time. Gorry is an invented word that sounds the same as gory, probably referencing the war, with its violence and blood, while gee, gosh and gum function as alternants. Poyatos (2002b, 142) defines alternants as "language free sighs, [...] moans, groans, grunts, sniffs, snorts, smacks, [...] gasps, pants, etc."; they are modified by kinesics. Here, alternants perform the function of involuntarily expressing an American man's feelings and emotions about the war. Another cultural paralinguistic referencing is found in: "Infinite lovely chatter of Bucks accent" (Gurney 1991, 82), which is a type of English spoken in southern England, familiar to the English reader, but not to the Croatian. The same can be said of Matošs $(1997,66)$ line: "Matija Gubec's tear / that bitter tear sweet as kaj", where the cultural reference is made not only through Matija Gubec, the famous 16th-century Croatian revolutionary, but through the association with a dialect spoken in the northern and central parts of Croatia.

It is no surprise that there were few culturally referenced paralinguistic elements, given that we have seen that the description of paralinguistic behaviour is much more problematic than the description of other types of nonverbal repertoires.

10 Originally in Croatian, translated by the author.

11 (1) Biological information - size, physique, sex, age, medical state; (2) psychological information - personality characteristics correlated with voice quality; and (3) social - features of voice acquired by imitation and culturally and socially learned (Laver 1991). 


\section{Conclusion}

This paper addresses the variety of nonverbal behaviours that constitute the triple structure of speech, that is, language-paralanguage-kinesics (Poyatos 1993) in war poems. The results show that culturally bound nonverbal elements are virtually non-existent in war poems, although these poems are based on actual historic events and such elements would be expected. The finding can lead us to conclude that the focus of poets is more on universal language, which together with traditional literary devices (verse, choice of words, figurative language, meter, form...), creates a successful backbone of poems in order to evoke the reality of an actual experience of war.

The majority of culturally referenced nonverbal behaviour is represented via spatial signs, body adaptors and bodily characteristics. Although less present than the former categories, paralinguistic and kinesic mechanisms, together with olfactory experiences, gustatory, auditory, tactile and kinesthetic mechanisms are of equal importance for the reader's experience of the poem. It is obvious that writing, when trying to transcend the possible 'orality' of speech, has its constraints and that describing paralinguistic behaviour is more difficult than describing the other nonverbal repertoire, which is one of the possible reasons for a small percentage of such elements in war poems.

By using carefully chosen words, the poets convey to the reader the wide range of acoustic and kinesic effects that humans use. Working together with conventional literary devices which set the overall tone and understanding of the poem, culturally bound nonverbal elements can still play a very important role in the overall impression. The power of nonverbal elements can be seen in Merezhkovsky's (1912, as quoted in Poyatos 2008, 41) words: "We experience in the muscles and nerves directing the expressive gestures of our own bodies, upon reading similar descriptions [...] And, by means of this sympathetic experience involuntarily going on in our own bodies [...] we enter into their internal world. We begin to live with them and in them."

\section{References}

Abrams, Meyer H. 1997. A Glossary of Literary Terms. 7th ed. Boston: Thomson Learning, Heinle \& Heinle.

Argyle, Michael. 1967. The Psychology of Interpersonal Behaviour. Harmondsworth: Penguin.

Benson, Leslie. 2001. Yugoslavia: A Concise History. Chippenham: Palgrave.

Blunden, Edmund. 1991. "Concert Party: Busseboom”. In The Norton Book of Modern War, edited by Paul Fussell, 138-39. New York: W.W. Norton \& Company.

Brooks, William D. 1978. Speech Communication. 3rd ed. Dubuque: Wm. C. Brown Company Publishers.

Carter, Ronald, and John McRae. 2001. The Routledge History of Literature in English. Britain and Ireland. 2nd ed. London: Routledge.

Crystal, David. 1975. The English Tone of Voice: Essays in Intonation, Prosody and Paralanguage. London: Edward Arnold.

Cummings, E. E. 1991a. "i sing of Olaf glad and big." In The Norton Book of Modern War, edited by Paul Fussell, 201-3. New York: W.W. Norton \& Company.

—. 1991b. "next to of course god America i." In The Norton Book of Modern War, edited by Paul Fussell, 2034. New York: W.W. Norton \& Company.

Docherty, Brian. 1995. “e.e. cummings." In American Poetry: The Modernist Ideal, edited by Clive Bloom and Brian Docherty. New York: St. Martin’s Press. 
Ekman, Paul, and Wallace V. Friesen. 1969. “The Repertoire of Nonverbal Behavior: Categories, Origins.” Semiotica 1 (1): 49-98. doi:10.1515/semi.1969.1.1.49.

Friesen, Wallace V., Paul Ekman, and Harald Wallbott. 1979. "Measuring Hand Movements." Journal of Nonverbal Behavior 4 (2): 97-112. doi:10.1007/BF01006354.

Fussell, Paul. 1991. "Introduction, on Modern War." In The Norton Book of Modern War, edited by Paul Fussell, 17-25. New York: W.W. Norton \& Company.

Guerrero, Laura K., and Kory Floyd. 2006. Nonverbal Communication in Close Relationships Mahwah: Lawrence Erlbaum Associates.

Gurney, Ivor. 1991. “The Silent One.” In The Norton Book of Modern War, edited by Paul Fussell, 82. New York: W.W. Norton \& Company.

Harrison, Randall P. 1974. Beyond Words; An Introduction to Nonverbal Communication. Englewood Cliffs: Prentice Hall.

Holoka, James, P. 1992. "Nonverbal Communication in the Classics: Research Opportunities." In Advances in Non-verbal Communication, edited by Fernando Poyatos, 237-54. Amsterdam: John Benjamins.

Johnstone, Philip. 1991. "High Wood.” In The Norton Book of Modern War, edited by Paul Fussell, 198. New York: W.W. Norton \& Company.

Jones, David. 1991. "In Parenthesis." In The Norton Book of Modern War, edited by Paul Fussell, 70-81. New York: W.W. Norton \& Company.

Kovačić, Ivan Goran. 2005. "Jama." In Sedam zvonara Majke Marije i druge pripovijetke, Jama, Izbor iz poezije, 113-27. Zagreb: Školska knjiga.

Krauss, Robert M., Yihsiu Chen, and Purnima Chawla. 1996. "Nonverbal Behavior and Nonverbal Communication: What do Conversational Hand Gestures Tell Us?” In Advances in Experimental Social Psychology, edited by Mark Zanna, 389-450. San Diego: Academic Press.

Krleža, Miroslav . 1976a. “Uspomena na Galiciju hiljadu devet stotina i šesnaeste.” In Poezija; Izbor za srednje škole, edited by Joža Skok and Dragutin Rosandić, 184. Zagreb: Školska knjiga.

—. 1976b. "Ulica u jesenje jutro godine devetstosedamnaeste." In Poezija; Izbor za srednje škole, edited by Joža Skok and Dragutin Rosandić, 186-200. Zagreb: Školska knjiga.

_. 1976c. "Na Trgu svetoga Marka." In Poezija; Izbor za srednje škole, edited by Joža Skok and Dragutin Rosandić, 77-78. Zagreb: Školska knjiga.

—. 1976d. "Nedjeljna pjesma." In Poezija; Izbor za srednje škole, edited by Joža Skok and Dragutin Rosandić, 182-83. Zagreb: Školska knjiga.

—. 1976e. "Rat." In Poezija; Izbor za srednje škole, edited by Joža Skok and Dragutin Rosandić, 180. Zagreb: Školska knjiga.

Lateiner, Donald. 1996. "Nonverbal Behaviors in Ovid's Poetry, Primarily 'Metamorphoses' 14." The Classical Journal 91 (3): 225-53. http://www.jstor.org/stable/3297604

Laver, John. 1991. The Gift of Speech; Papers in the Analysis of Speech and Voice. Edinburgh: Edinburgh University Press.

Laver, John, and Sandy Hutcheson. 1972. Communication in Face to Face Interaction: Selected Readings. Harmondsworth: Penguin Books.

Lennard, John 2005. The Poetry Handbook. A Guide to Reading Poetry for Pleasure and Practical Criticism. 2nd ed. New York: Oxford University Press.

Lucas, Stephen E. 2009. The Art of Public Speaking. 10th ed. New York: McGraw-Hill. 
Lyons, John. 1981. Language and linguistics; An introduction. Cambridge: Cambridge University Press.

McKerrow, Raymie E., Bruce E. Gronbeck, Douglas Ehninger, and Alan H. Monroe. 1999. Principles and Types of Speech Communication. 14th ed. Reading: Addison Wesley Longman.

Meyer, Michael. 1987. "Reading Imaginative Literature" In The Bedford Introduction to Literature, edited by Michael Meyer, 3-7. New York: St Martin’s Press.

Newmark, Peter. 1988. A Textbook of Translation. Hertfordshire: Prentice Hall.

Oliver, Mary. 1994. A Poetry Handbook. San Diego: Harcourt Brace \& Company.

Pavlović, Nataša, and Darko Poslek. 1998. "British and Croatian Culture-Specific Concepts in Translation." In British Cultural Studies: Cross-Cultural Proceedings, edited by Janja Ciglar-Žanić, Damir Kalogjera, and Jasna Jemeršić. 157-69. Zagreb: The British Council Croatia.

Poyatos, Fernando. 1975. "Cross -Cultural Study of Paralinguistic 'Alternants' in Face-to Face Interaction.” In Organization of Behavior in Face-to-Face Interaction, World Anthropology, edited by Adam Kendon, Richard M. Harris, and Mary Ritchie Key. 285-314. The Hague: Mouton \& Co.

- 1993. Paralanguage: A Linguistic and Interdisciplinary Approach to Interactive Speech and Sound. Amsterdam: John Benjamins.

—. 2002a. Nonverbal Communication across Disciplines; Volume I. Culture, Sensory Interaction, Speech, Conversation. Amsterdam: John Benjamins.

—. 2002b. Nonverbal Communication across Disciplines; Volume II. Paralanguage, Kinesics, Silence, Personal and Environmental Interaction. Amsterdam: John Benjamins.

-. 2008. Textual Translation and Live Translation; The Total Experience of Nonverbal Communication in Literature, Theater and Cinema. Amsterdam: John Benjamins.

Reusch, Jurgen, and Weldon Kees. 1971. Nonverbal Communication: Notes on the Visual Perception of Human Relations. 2nd ed. Berkeley: University of California Press.

Sapir, Edward. 1970. Language. New York: Harcourt Brace.

Sassoon, Siegfried. 1991a. "Aftermath: March 1919." In The Norton Book of Modern War, edited by Paul Fussell, 199-200. New York: W.W. Norton \& Company.

—. 1991b. "The General." In The Norton Book of Modern War, edited by Paul Fussell, 68-69. New York: W.W. Norton \& Company.

Scannell, Vernon. 1991. "The Great War." In The Norton Book of Modern War, edited by Paul Fussell, 204-5. New York: W.W. Norton \& Company.

Ujević, Tin. 2004. "Patriotski značaj ima promenada." In Medaši; Hrvatsko pjesništvo dvadesetog stoljeća, edited by Zvonimir Mrkonjić, 151. Zagreb: Profil.

—. 2005. "Pokrajina.” In Izbor pjesama I., edited by Ante Stamać, 99-100. Zagreb: Matica Hrvatska. 